\title{
CENTENARY OF QUEEN'S UNIVERSITY, KINGSTON, CANADA
}

\author{
By Dr. R. C. WALlace \\ Principal and Vice-Chancellor
}

$\mathrm{O}^{\mathrm{N}}$ October 16, 1841, a Royal Charter was granted to Queen's College, to be established in Kingston in Canada. The Presbyterian Church of Canada, resentful of the position which had been taken by the Anglicans in the management of higher education, felt that it was necessary to have a college at which men might be educated in arts and theology for the ministry of the Church, and made application for the charter. Thus Queen's began as a denominational college, and remained under denominational control until 1912, when the Presbyterian Church relinquished all connexion with the University. A Theological College then was established under separate administration, though closely connected with the University, and was associated with the Presbyterian Church until 1925, when, on the Union of Presbyterians, Methodists and Congregationalists in Canada, the Theological College became affiliated with the United Church of Canada, and still maintains that affiliation.

From the beginning the College took a liberal view of its responsibilities. It established teaching in the humanities, mathematics and theology, but almost immediately decided to embark on the teaching of medicine. The Faculty of Medicine was eventually established in 1856. Applied science came later, when the need developed for mining engineers and metallurgists to guide the growing mining industry in Canada. The School of Mines was set up in. 1883 , and when its activity had widened it was incorporated as a Faculty of Applied Science in 1916. Courses in commerce, banking and chartered accountancy, which had been carried on in association with the Faculty of Arts for several years, were organized under a School of Commerce in 1937.

These are the dry bones of detail of organization. They are not the things that are most in mind when one thinks of the hundred years which have passed over the head of the embryo Queen's College of 1841. Some of the more intangible elements of the story of Queen's University deserve mention, for they have much to do with the remarkable sense of loyalty and devotion which the graduates of Queen's show to their Alma Mater.

The most striking fact in the history of Queen's University is the constant struggle against difficulties, financial and otherwise, with which the institution was faced. Few universities are free from financial worries, but Queen's in her history has had more than her share. In time of difficulty students as well as staff took off their coats and worked, until the situation was relieved. Out of this sharing of hard times together there developed a sense of co-operate responsibility which has welded Queen's people into a solid community.

A second fact of importance in giving the University its own individuality has been the personality of the teachers. The older graduates, when they gather together, recall the days under the outstanding administration of George Munro Grant, when a galaxy of men, such as it has been the good fortune of few university heads to gather together, moulded the intellectual life and character of those who were fortunate enough to sit at their feet. Grant was a great Canadian statesman, who gave Queen's the status of a national university ; and Watson, McNaughton, Jordan, Dupuis, Shortt and Cappon were names to conjure with. We like to feel that Queen's has not departed from the tradition. It is, par excellence, a teaching university.

Its service to teaching and to education found a special method of expression. Queen's instituted a system of extramural correspondence courses, by means of which students who could not take the winter terms at the University were able by correspondence work and summer sessions to complete the work for the degree, the condition being that more than half the work must be taken intramurally. This system, in which Queen's was the pioneer and is still the chief exponent, has been of very great service to the teaching profession throughout the Dominion. In normal years, in a student body of 4200 , some 2400 are taking courses under the extra-mural system, and are sitting for the regular university examinations for the degree in arts, or the special examinations of the Institute of Chartered Accountants or the Canadian Bankers' Association.

The University has made a special contribution to the public services. Under the direction successively of Shortt, Skelton, Clark, Norman Rogers, McArthur and Mackintosh, all of whom have given distinguished service to the public administration, a. long list of Queen's students have gone into the public life of Canada. Ottawa has leaned heavily on Queen's for men, and continues to do so; while in the provinces, and more particularlv in 
Ontario, the Civil Service has drawn in large measure from those who received their inspiration from the men who served Queen's on the teaching staff, and served their country later in significant administrative capacities.

Though the emphasis has been on teaching, Queen's has not failed in contribution to knowledge during these years. John Watson was for more than thirty years the exponent of speculative idealism on the American continent, and he exercised a very real influence on philosophical thought. Jordan and Scott led a school of liberal interpretation of theological dogma. Cappon, sparing in writing, was recognized to be one of our ablest Canadian literary critics Shortt had proved himself to be an authority on banking and currency before he undertook to reorganize the Civil Service system at Ottawa. Skelton, in like manner, had become known for his researches in Canadian political history before he went to Ottawa to build up the Department of External Affairs. The economic studies of Mackintosh, and the studies in Canadian history of McArthur, Trotter and Graham, maintain for Queen's a high place in the social sciences.

In the physical and natural sciences, the Univer- sity has gained a reputation in geology, for which Brock and Miller laid the foundation, now maintained by Bruce and his fellow-workers. The practical problems in the Canadian Northland, from the metallurgical point of view, have been faced by Kirkpatrick, who made an important contribution to the recovery and utilization of cobalt. Clark has done much work on the critical state of fluids, and Gray is well known for the contributions he and his co-workers have made to knowledge of atomic structure. One need only name the work of Humphrey in psychology, Vlastos in social ethics, Miller in pathology, Sinclair and Boyd in lipids, Reid in gas gangrene, Hebb in intelligence testing, McRae in organic synthesis, Ettinger in physiological reactions, to refer only to a few of the present-day workers, to show that in variety and-may I add-in quality of scientific research Queen's is playing its part.

Queen's celebrates its centenary by reviewing the progress of thought during the last hundred years. To that progress universities have made important contributions. In the development of knowledge during the next hundred years the universities will have an even greater part to play.

\section{OBITUARIES}

Dr. Walter Gardiner, F.R.S.

$\mathrm{T}$ HE name of Walter Gardiner, whose death occurred on August 31, will always be remembered by botanists and physiologists for his epochmaking histological researches and discoveries on the continuity of protoplasm. Owing to many years of ill-health, he was unknown to recent scientific workers, except by his classic papers.

Born on September 1, 1859, he died on the eve of his eighty-second birthday and was one of the veteran fellows of the Royal Society-only three now living having been elected before 1890 , the year of his election, at the early age of thirty and a half years.

He was the younger son of Mr. Stephen T. Gardiner and was born at Burwell, on the edge of the Fens, between Cambridge and Newmarket. $\mathrm{He}$ was educated at Bedford and was a scholar of the Royal Agricultural Society during 1874-1876, and proceeded with a scholarship to Clare College, Cambridge. In 1881 Gardiner obtained first elass honours in the Natural Sciences Tripos and took his B.A. degree in 1882 and M.A. in 1885 , in which year he was elected to a fellowship at Clare College; afterwards he was made an honorary fellow of the College (1915). In 1883 he was appointed science lecturer at Girton College and the following year,
University demonstrator in botany. This post he held until 1888 when he was promoted University lecturer. He resigned the lectureship in 1897 . He was elected bursar of Clare College in 1895.

Gardiner was associated with the Cambridge Botany School during the last years of Prof. C. C. Babington's professorship, when botanical teaching and research was at a low ebb and was being conducted mainly on uninspiring descriptive lines. The appointment of S. H. Vines, however, as reader in botany in 1883 and his conjunction with Francis Darwin, opened a new era in Cambridge botany. Into this new atmosphere Gardiner threw himself with energy, giving remarkable lectures to the advanced students, building up the Museumfounded originally by Prof. J. S. Henslow-and carrying on his own histological researches, in which he was influenced and greatly encouraged by Michael Foster and by Thiselton-Dyer, then assistant director of Kew.

Botanical teaching in Great Britain being so unsatisfactory, as Prof. F. O. Bower has pointed out in his "Sixty Years of Botany in Britain", Gardiner, like several other young botanists, went to Germany and he worked in the Botanical Institute at Würzburg during the summer of 1882 under Prof. J. von Sachs, for whom he had a profound admiration. At 